\title{
SHAKESPEARE-LEXICON.
}

\section{A COMPLETE DICTIONARY}

OF ALL THE ENGLISH WORDS, PHRASES AND CONSTRUCTIONS

IN THE WORKS OF THE POET.

BY

ATHXANDGR SCEMIDT, LL. D.

SECOND EDITION.

VOLUME I.

A-L.

1886.

BERLIN.

LONDON.

GE ORG R I I ER. MLLAYS EOBGATE. 
